\title{
PENGARUH MOTIVASI DAN ETIKA KERJA ISLAM TERHADAP KOMITMEN ORGANISASI DI KOPERASI KARYAWAN PURA GROUP KUDUS
}

\author{
Fathiyyatul Limanihtada \\ Suhadi \\ Institut Agama Islam Negeri Kudus
}

\begin{abstract}
This study aims to determine the effect of work motivation and Islamic work ethics on organizational commitment in the Pura Group Kudus Employee Cooperative. This type of research is field research, with a quantitative research approach. The number of research samples was 30 respondents. Primary data was obtained from questionnaires / questionnaires and processed using SPSS. The results showed that work motivation had a significant effect on organizational commitment, as evidenced by the value of $t$ arithmetic $(1.720>1.703)$ and $\rho$ value of 0.097. Whereas Islamic work ethic influences but is not significant to organizational commitment, evidenced by the value of $t$ arithmetic $(2.260>1.703)$ and $\rho$ value of 0.032 .
\end{abstract}

Keywords: Motivasi Kerja, Etika Kerja Islam, Komitmen Organisasi.

\section{PENDAHULUAN}

Organisasi adalah proses kerjasama sejumlah manusia (dua orang atau lebih) untuk mencapai tujuan bersama. Semua organisasi memiliki kesamaan, dan hanya berbeda dalam bidang geraknya saja yang didasari oleh kepentingan yang sama dari manusia yang menghimpun diri dalam suatu organisasi. Begitu pula organisasi yang bergerak dalam bidang bisnis, yang dibentuk oleh sejumlah orang yang memiliki kepentingan untuk memperoleh penghasilan, yang diperlukan oleh setiap manusia dewasa dalam memenuhi kebutuhan diri sendiri dan keluarganya. Kepentingan itu hanya dapat dipenuhi dengan melakukan kegiatan bisnis yang memberikan keuntungan sebagai tujuan akhir organisasinya (Hadari Nawawi, 2011: 13).

Dalam organisasi tersebut, tidak dapat dipungkiri bahwa faktor sumber daya manusia merupakan satu unsur yang berperan penting dalam keberhasilan suatu organisasi. Prestasi, dedikasi dan loyalitas dari seseorang secara langsung atau tidak langsung akan mempengaruhi kesuksesan suatu organisasi. Dibalik kesuksesan akan produk atau jasa yang dihasilkan suatu perusahaan, terdapat tangan-tangan mungil para pekerja atau sumber daya manusia yang patut dipertahankan. Dengan kondisi tersebut, saat ini sebuah organisasi berusaha untuk menciptakan sumber daya manusia sebagai satu aset yang secara konsisten harus ditingkatkan efisiensi dan produktivitasnya. Disini organisasi ditantang untuk mampu bersaing dengan organisasi- organisasi lain dalam 
mempertahankan sumber daya yang mereka miliki, agar tidak lari atau meninggalkan organisasi.

Sebagaimana yang kita ketahui cara paling absolute yang dapat membuat anggota organisasi tetap tinggal dalam organisasi adalah dengan menumbuhkan "komitmen organisasi". Seperti yang dinyatakan oleh Steers, dengan adanya komitmen berarti mereka memiliki; pertama, kepercayaan dan penerimaan yang kuat atas tujuan dan nilai-nilai organisasi. Kedua, kemauan untuk mengusahakan tercapainya kepentingan organisasi. Ketiga, keinginan yang kuat untuk mempertahankan keanggotaan organisasi (Sopiah, 2008:156)

Maka dari itu, adanya komitmen pada diri anggota organisasi tidak hanya membuat mereka tetap tinggal di organisasi, akan tetapi lebih dari itu mereka akan bekerja dengan baik sesuai dengan apa yang diharapkan organisasi. Robert Walton, penulis berkebangsaan Amerika yang menyoroti pentingnya komitmen menyebutkan bahwa kinerja perusahaan akan meningkat apabila organisasi meninggalkan model pengendalian tradisional dalam manajemen karyawan. Pendekatan tersebut sebaiknya digantikan dengan strategi komitmen. Ia menyarankan bahwa karyawan akan memberikan respon terbaik dan menjadi sangat kreatif apabila diberikan tanggungjawab yang lebih luas, dorongan untuk berkontribusi serta bantuan untuk mencapai kepuasan kerja (Sunarto, 2005: 25)

Obyek dan subyek manajemen SDM adalah manusia sebagai pekerja di lingkungan organisasi. Pekerja sebagai manusia memiliki hakikat sebagai makhluk individual, sosial dan normatif. Individual menunjukkan bahwa selain memilikikesamaan fisik dan psikologis, ternyata setiap manusia memiliki pula perbedaan dalam kedua substansi itu, sehingga menjadi individu yang tidak sama satu dengan yang lain. Sosialitas menunjukkan realisasi dan aktualisasi diri setiap manusia sebagai individu yang membutuhkan dan tidak dapat melepaskan diri antara yang satu dengan yang lain. Kondisi ini menjadikan manusia sebagai makhluk sosial yang memerlukan kehidupan bersama dalam kebersamaan untuk dapat hidup secara manusiawi. Kehidupan bersama dalam kebersamaan itu disebut masyarakat (Hadari Nawawi, 2011: 350).

Hakikat moralitas berupa kecenderungan pada norma-norma dan nilai- nilai yang memungkinkannya hidup sesuai harkat dan martabatnya sebagai manusia. 
Kecenderungan inilah yang mendasari kemampuan manusia untuk mengenali batasbatas yang harus dihormati dan diwujudkannya untuk dapat hidup bersama didalam masyarakat, termasuk juga didalam organisasi (Hadari Nawawi, 2011: 4).

Sejumlah pekerja di lingkungan suatu organisasi adalah sebuah masyarakat tersendiri dengan karakternya masing-masing. Suasana psikologis seorang pekerja sebagai individu dalam masyarakat organisasi yang menjadi lingkungan kerjanya sangat besar pengaruhnya pada pelaksanaan pekerjaannya. Suasana batin itu nampak dalam semangat dan gairah kerja yang menghasilkan kegiatan kerja sebagai kontribusi bagi pencapaian tujuan bisnis organisasi tempatnya bekerja. Dari segi psikologis, kenyataan menunjukkan bahwa semangat dan gairah kerja seseorang sangat dipengaruhi oleh motivasi kerja. Dengan kata lain setiap pekerja memerlukan motivasi yang kuat agar bersedia melaksanakan pekerjaan dengan semangat, bergairah dan berdedikasi (Hadari Nawawi, 2011: 351).

Toto Tasmara, (1995: 2) bekerja adalah fitrah dan sekaligus merupakan salah satu identitas manusia, sehingga bekerja yang didasarkan pada prinsip-prinsip iman tauhid, bukan saja menunjukkan fitrah seorang muslim, tetapi sekaligus meninggikan martabat dirinya sebagai "abdullah (hamba Allah)" yang mengelola seluruh alam sebagai bentuk dari cara dirinya mensyukuri kenikmatan dari Allah. Sebagai seorang muslim, kita dituntut untuk tidak hanya mementingkan akhirat saja atau duniawi saja, tetapi di tengah-tengah antara keduanya, yaitu jangan sampai dilalaikan oleh pekerjaan mencari harta saja, tapi berusahalah selalu dekat dengan Allah (Buchari Alma dan Donni Juni Priansa, 2009: 158).

Dalam pemilihan objek penelitian, penulis melihat adanya komitmen organisasi yang tinggi pada karyawan-karyawan Kopkar Pura Group, dilihat dari lamanya bekerja karyawan-karyawan tersebut. Untuk itu, dari kedua variabel motivasi kerja dan etika bisnis Islam yang unik ini, dan ditambah objek penelitian yang sudah sangat tepat, peneliti terinspirasi untuk melakukan penelitian tentang "Pengaruh Motivasi Kerja Dan Etika Kerja Islam Terhadap Komitmen Organisasi Di Koperasi Karyawan Pura Group Kudus". Tujuan dari penelitian ini untuk menguji secara empiris pengaruh motivasi kerja dan etika kerja Islam terhadap komitmen organisasi karyawan Koperasi Karyawan Pura Group.

\section{LANDASAN TEORI}




\section{Motivasi Kerja}

Motif sering diartikan dengan istilah dorongan. Dorongan tersebut adalah gerak jiwa dan jasmani untuk berbuat. Dengan demikian, motif merupakan suatu driving force yang menggerakkan manusia untuk bertingkah laku, dan dalam perbuatannya itu terdapat tujuan tertentu. Wexley dan Yukl memberikan batasan mengenai motivasi sebagai "The process by which behavior is energized and directed". Ahli yang lain memberikan kesamaan antara motif dan kebutuhan. Dari batasan tersebut bisa disimpulkan bahwa motivasi adalah sesuatu yang melatarbelakangi perbuatan individu untuk mencapai tujuan tertentu (Khaerul Umam, 2010: 159).

1. Tujuan Motivasi Kerja

Ahli di bidang manajemen sumber daya manusia, Saydam mengemukakan tujuan motivasi kerja adalah:3

a. Mengubah perilaku karyawan sesuai dengan keinginan perusahaan

Mengubah perilaku yang dimaksud disini adalah perilaku kerja. Dengan adanya motivasi kerja pada diri karyawan, mereka akan tetap bersedia melaksanakan pekerjaan sesuai dengan kecakapan yang mereka miliki. Bukan hanya melaksanakan pekerjaan asal saja, tetapi benar-benar melakukannya sesuai dengan tujuan dan keinginan perusahaan.

b. Meningkatkan gairah dan semangat kerja

Persoalan-persoalan manusia hanya bisa dipecahkan manusia pula, dengan menggunakan data dan alat-alat kemanusiaan. Kondisi mental psikis pegawai amat besar pengaruhnya terhadap produktivitas kerja. Jadi dengan memperlakukan mereka dengan baik dan wajar, pegawai mampu termotivasi yang pada akhirnya dapat meningkatkan gairah dan semangat kerja.

c. Meningkatkan disiplin kerja

Motivasi kerja akan mendorong pegawai bersedia memberikan waktu, tenaga dan pikirannya untuk melaksanakan pekerjaan dalam organisasi yang menjadi tempat kerjanya.

d. Meningkatkan prestasi kerja

Meningkatkan rasa tanggung jawab Meningkatkan produktivitas dan efisiensi

e. Meningkatkan rasa tanggung jawab 
Tanggung jawab ini bukan hanya atas hasil kerja yang baik, tetapi juga tanggung jawab berupa kepercayaan yang diberikan sebagai orang yang mempunyai potensi.

f. Meningkatkan produktivitas dan efisiensi

Kondisi kerja amat menentukan tingkat gairah kerja para pegawainya. Apabila kerja dirasa menyenangkan, menyejukkan dan tidak bising, maka semua pegawai akan termotivasi untuk bekerja giat yang selanjutnya akan meningkatkan produktivitas dan efisiensi.

g. Menumbuhkan loyalitas karyawan pada perusahaan

Motivasi kerja merupakan modal utama loyalitas pegawai terhadap organisasi. Dengan kata lain loyalitas tidak dapat diwujudkan bila para pegawai tidak memiliki motivasi

kerja.

\section{Faktor-faktor Motivasi Kerja}

Motivasi sebagai proses psikologis dalam diri seseorang akan dipengaruhi oleh beberapa faktor, dimana faktor-faktor tersebut dibedakan menjadi dua (Khaerul Umam, 2010: 296-301), yaitu faktor intern yang terdapat pada diri karyawan itu sendiri, dan kedua faktor ekstern yang berasal dari luar diri karyawan.

Maslow memisahkan kelima kebutuhan ini sebagai tingkat tinggi dengan tingkat rendah. Kebutuhan psikologis dan keamanan digambarkan sebagai kebutuhan tingkat rendah, sementara kebutuhan sosial, penghargaan dan aktualisasi diri ditempatkan ke dalam tingkat tinggi. Perbedaan antara kedua tingkat tersebut didasarkan pada alasan bahwa kebutuhan tingkat tinggi dipenuhi secara internal (dalam diri orang) sedangkan kebutuhan tingkat rendah dipenuhi secara eksternal (upah, kontrak sebagai buruh, dan masa kerja misalnya). (Khaerul Umam, 2010: 162).

Komang Ardana dkk (2008: 31), berpendapat bahwa faktor-faktor yang mempengaruhi motivasi seseorang adalah sebagai berikut: 1) Karakteristik individu, antara lain: minat, sikap terhadap diri sendiri, pekerjaan dan situasi pekerjaan, kebutuhan individual kemampuan atau kompetensi, pengetahuan tentang pekerjaan, emosi, suasana hati, perasaan keyakinan dan nilai-nilai 2) Faktor-faktor pekerjaan, antara lain: (a) Faktor lingkungan pekerjaan, yaitu: gaji yang diterima, kebijakankebijakan sekolah, supervisi, hubungan antar manusia, kondisi pekerjaan, budaya 
organisasi; (b) Faktor dalam pekerjaan, yaitu: sifat pekerjaan, rancangan tugas atau pekerjaan, pemberian pengakuan terhadap prestasi, tingkat atau besarnya tanggung jawab yang diberikan, adanya perkembangan dan kemajuan dalam pekerjaan, adanya kepuasan dari pekerjaan.

\section{Etika Kerja Islam}

Istilah etika kerja dapat diartikan sebagai etos kerja. Etos berasal dari bahasa Yunani "ethikos, yang berarti moral atau menunjukkan karakter moral. Etos mempunyai arti sebagai keberadaan diri, jiwa dan pikiran yang membentuk seseorang. Etika bukan hanya dimiliki bangsa tertentu. Masyarakat dan bangsa apapun memiliki etika yang merupakan nilai-nilai universal. Nilai-nilai etika yang dikaitkan dengan etos kerja seperti rajin, bekerja keras, disiplin tinggi, menahan diri, ulet, tekun, dan nilai-nilai etika lainnya bisa juga ditemukan pada masyarakat dan bangsa lain (Abdul Aziz, 2013: 192).

Toto Tasmara, (2002: 25) mendefinisikan makna bekerja bagi seorang muslim adalah suatu upaya sungguh-sungguh dengan mengerahkan seluruh asset dan zikirnya untuk mengaktualisasikan atau menampakkan arti dirinya sebagai hamba Allah yang menundukkan dunia dan menempatkan dirinya sebagai bagian dari masyarakat yang terbaik atau dengan kata lain dapat juga dikatakan bahwa dengan bekerja manusia memanusiakan dirinya. Lebih lanjut dikatakan bekerja adalah aktivitas dinamis dan mempunyai tujuan untuk memenuhi kebutuhan tertentu (jasmani dan rohani) dan di dalam mencapai tujuannya tersebut dia berupaya dengan penuh kesungguhan untuk mewujudkan prestasi yang optimal sebagai bukti pengabdian dirinya kepada Allah SWT.

Nilai-nilai Etika Kerja Islam

Buchari Alma dan Donni Juni Priansa, (2009: 205-207) mengemukakan nilainilai yang terkandung dalam etika kerja Islam adalah sebagai berikut:

a. Konsep Ihsan

Ihsan berarti individu berusaha untuk bersungguh-sungguh bekerja, tanpa kenal menyerah dengan dedikasi penuh menuju pada optimalisasi, sehingga memperoleh hasil maksimal.

b. Itqan 
Itqan mempunyai arti membuat sesuatu dengan teliti dan teratur. Hal ini dapat terlihat dari peningkatan yang dicapai, apakah pekerjaan yang dilakukan sudah maksimal atau belum.

c. Konsep Hemat

Rasulullah SAW telah mengajarkan pada umatnya untuk bersikap hemat dengan harta, tapi tidak kikir dan tidak menggunakannya kecuali untuk sesuatu yang benar-benar bermanfaat.

d. Kejujuran dan Keadilan

Dua nilai ini merupakan konsep yang menciptakan ketenangan hati bagi orang yang memilikinya. Kejujuran membuat orang lain senang berteman dan menjalin hubungan dengan orang tersebut.

e. Kerja Keras

Dijelaskan dalam Al-Qur'an:

Artinya: "Dan orang-orang yang berjihad untuk (mencari keridhaan) Kami, benarbenar akan Kami tunjukkan kepada mereka jalan-jalan Kami. Dan sesungguhnya Allah benar-benar beserta orang-orang yang berbuat baik. ${ }^{2}$ (Q.S Al-Ankabuut: 69)

\section{Komitmen Organisasi}

Menurut Minner (dalam Sopiah, 2008) mengemukaan empat faktor yang mempengaruhi komitmen karyawan antara lain faktor personal, karakteristik pekerjaan, karakteristik struktur, dan pengalaman kerja. Sebab tingkat komitmen anatara karyawan yang memang sudah puluhan tahun bekerja akan berbeda dengan karyawan yang baru saja bekerja.

\section{Bentuk Komitmen Organisasi}

Menurut Meyer, Allen dan Smith dalam Spector, ada tiga komponen komitmen organisasi, yaitu:

a. Affective commitment, terjadi apabila karyawan ingin menjadi bagian dari organisasi karena adanya ikatan emosional.

b. Continuance commitment, muncul apabila karyawan tetap bertahan pada suatu oganisasi karena membutuhkan gaji dan keuntungan- keuntungan lain, atau karena karyawan tersebut tidak menemukan pekerjaan lain. 
c. Normative commitment, timbul dari nilai-nilai dalam diri karyawan.

Karyawan bertahan menjadi anggota organisasi karena adanya kesadaran bahwa komitmen terhadap organisasi merupakan hal yang seharusnya dilakukan (Sopiah, 2008: 155).

\section{Proses Terjadinya Komitmen Organisasi}

Terjadinya komitmen melewati tiga fase yang dijelaskan oleh Minner, yaitu:

a. Initial Commitment

Pada fase awal ini, faktor yang berpengaruh terhadap komitmen karyawan pada organisasi adalah factor personal yang meliputi karakteristik individu, harapanharapan karyawan pada organisasi, dan karakteristik pekerjaan.

b. Commitment During Early Employment

Pada fase ini karyawan sudah bekerja beberapa tahun. Faktor- faktor organisasi mempengaruhi komitmen pada fase ini, yaitu pengalaman kerja yang dirasakan pada tahap awal bekerja, bagaimana pekerjaannya, bagaimana sistem penggajiannya, bagaimana gaya supervisinya, bagaimana hubungan dengan teman atau hubungan dengan pimpinan. Semua ini akan membentuk komitmen awal dan tanggung jawab karyawan pada organisasi yang pada akhirnya bermuara pada komitmen karyawanpada awal memasuki dunia kerja.

c. Commitment During Later Career

Tahap terakhir komitmen yang dipengaruhi oleh investasi, mobilitas kerja, hubungan sosial yang tercipta di organisasi dan pengalaman-pengalaman selama bekerja (Sopiah, 2008: 155).

\section{METODE PENELITIAN}

Jenis penelitian ini adalah penelitian lapangan, dengan menggunakan pendekatan kuantitatif. Populasi dalam penelitian ini adalah seluruh karyawan yang bekerja di Koperasi Karyawan Pura Group sejumlah 55 orang. Sampel dalam penelitian sebanyak 30 . Variabel independen dalam penelitian ini adalah motivasi kerja $\mathrm{X}_{1}$ dan etika kerja Islam $\mathrm{X}_{2}$, sedangkan variabel dependen adalah komitmen organisasi(Y). Metode analisis data menggunakan analisis deskriptif analisis statistic, yaitu analisis regresi linier berganda, Uji koefisien regresi secara parsial (Uji t), analisis determinasi $\left(\mathrm{R}^{2}\right)$ 
Persamaan regresi:

$$
\mathrm{Y}=\mathrm{a}+\mathrm{b}_{1} \mathrm{X}_{1}+\mathrm{b}_{2} \mathrm{X}_{2}+\mathrm{e}
$$

Keterangan:

$$
\begin{array}{ll}
\mathrm{Y} & =\text { Komitmen organisasi } \\
\mathrm{a} & =\text { Konstanta } \\
\mathrm{b}_{1} & =\text { Koefisien regresi motivasi kerja } \\
\mathrm{b}_{2} & =\text { Koefisien regresi etika kerja Islam } \\
\mathrm{X}_{1} & =\text { Motivasi kerja } \\
\mathrm{X}_{2} & =\text { Etika kerja Islam } \\
\mathrm{e} & =\text { Variabel independen lain di luar model regresi }
\end{array}
$$

\section{HASIL PENELITIAN}

\section{Analisis Data}

1. Analisis Regresi Linier Berganda

Model analisis regresi linier berganda ini digunakan untuk mengetahui pengaruh motivasi kerja dan etika kerja Islam terhadap komitmen organisasi di KOPKAR PURA Group Kudus. Dari estimasi diperoleh hasil sebagai berikut:

Tabel 1

Hasil Regresi Linier

Berganda

\begin{tabular}{lc}
\hline Keterangan & Nilai Koefisien \\
\hline Konstanta & 2.616 \\
Motivasi kerja (X1) & 0.334 \\
Etika Kerja Islam (X2) & 0.439
\end{tabular}

\section{Sumber: Data Primer yang diolah}

Dari tabel diatas diperoleh persamaan regresi pengaruh motivasi kerja dan etika kerja Islam terhadap komitmen organisasi di KOPKAR PURA Group Kudus sebagai berikut:

$$
\mathrm{Y}=2.616+0.334 \mathrm{X}_{1}+0.439 \mathrm{X}_{2}+\mathrm{e}
$$

2. Uji Koefisien Regresi Secara Parsial (Uji t)

Pengujian parsial (uji t) bertujuan untuk mengetahui apakah variabel independen yang terdapat dalam persamaan regresi secara individu berpengaruh terhadap nilai 
variabel dependen. Secara lebih rinci t hitung dijelaskan dalam tabel sebagai berikut ini:

Tabel 2

Hasil Uji t

\begin{tabular}{|c|c|c|c|c|}
\hline Variabel & t hitung & t tabel & Sig. & Interprestasi \\
\hline Motivasi Kerja (X1) & 1.720 & 1.703 & .097 & Berpengaruh \\
\hline $\begin{array}{lll}\text { Etika } & \text { Kerja } & \text { Islam } \\
(\mathrm{X} 2) & & \end{array}$ & 2.260 & .703 & .032 & Berpengaruh \\
\hline
\end{tabular}

Sumber: Data Primer yang diolah

a. Pengaruh Motivasi Kerja terhadap Komitmen Organisasi

Dari hasil uji $\mathrm{t}$ untuk variabel bebas (motivasi kerja) menunjukkan $\mathrm{t}$ hitung 1.720 dengan $t$ tabel 1.703 dan $\rho$ value sebesar 0.097 yang berada di bawah $5 \%$ tingkat signifikasi. Ini berarti nilai t hitung lebih besar dari t tabel $(1.720>1.703)$. Dengan demikian motivasi kerja merupakan variabel bebas yang berpengaruh secara positif dan signifikan terhadap komitmen organisasi.

Hasil penelitian ini mendukung hipotesis alternative yang menyatakan "motivasi kerja berpengaruh positif dan signifikan terhadap komitmen organisasi”. Hal ini dikarenakan motivasi kerja merupakan modal utama loyalitas, loyalitas pegawai terhadap organisasi, sebagai penggerak atau pendorong dalam diri seseorang untuk mau berperilaku dan bekerja dengan giat dan baik sesuai dengan tugas dan kewajiban yang telah diberikan kepadanya. Sehingga apabila seseorang memiliki motivasi kerja dalam dirinya, maka loyalitas/komitmen organisasi sudah dapat dipastikan juga dimilikinya.

b. Pengaruh Etika kerja Islam terhadap Komitmen Organisasi

Dari hasil uji $\mathrm{t}$ untuk variabel bebas (motivasi kerja) menunjukkan $\mathrm{t}$ hitung 2.260 dengan t tabel 1.703 dan $\rho$ value sebesar 0.032 yang berada di bawah 5\% tingkat signifikasi. Ini berarti nilai t hitung lebih besar dari t tabel $(2.260>1.703)$. Dengan demikian etika kerja Islam merupakan variabel bebas yang berpengaruh secara positif, tapi tidak signifikan terhadap komitmen organisasi di Koperasi Karyawan Pura Group ini.

Dilihat dari besarnya $\mathrm{t}$ hitungnya, hasil penelitian ini memberikan bukti bahwa etika kerja Islam merupakan salah satu ciri dari adanya komitmen organisasi, 
yang mana semakin meningkat etika kerja Islam yang dimiliki seseorang, maka semakin tinggi pula komitmen organisasi yang dimiliki.

3. Analisis Determinasi (R2)

Analisis determinasi digunakan untuk mengetahui prosentase sumbangan pengaruh variabel independen (motivasi kerja dan etika kerja Islam) secara serentak terhadap variabel independen (komitmen organisasi). Koefisien ini menunjukkan seberapa besar prosentase variasi variabel independen yang digunakan dalam model mampu menjelaskan variasi variabel dependen.

Tabel 3

Hasil Analisis Determinasi

Model Summary

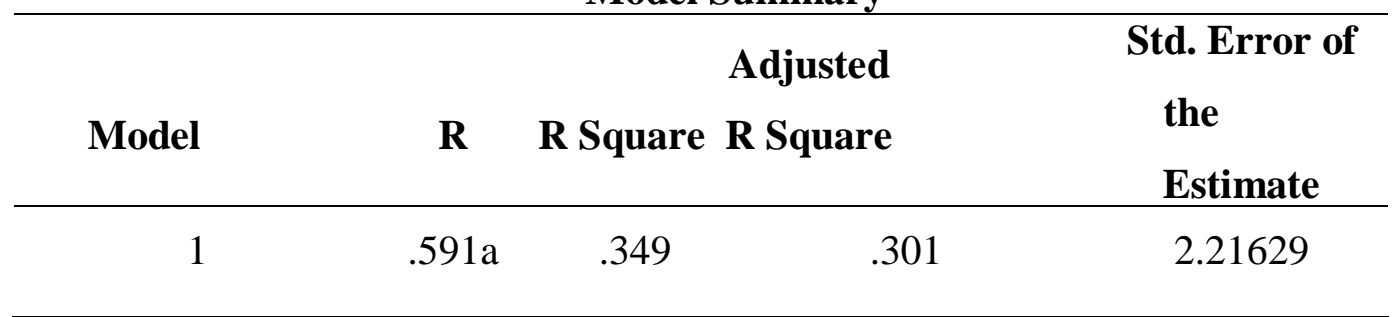

a. Predictors: (Constant), VAR00002, VAR00001

Sumber: Data Primer yang diolah.

Berdasarkan hasil analisis determinasi, diperoleh angka R2 (R square) sebesar 0.349 atau $34.9 \%$. Hal ini menunjukkan bahwa persentase sumbangan pengaruh variabel independen (motivasi kerja dan etika kerja Islam) mampu menjelaskan sebesar $34.9 \%$ variasi variabel dependen (komitmen organisasi). Sedangkan sisanya sebesar $65.1 \%$ dipengaruhi atau dijelaskan oleh variabel lain yang tidak dimasukkan dalam model penelitian ini.

\section{SIMPULAN}

Berdasarkan pembahasan pada bab sebelumnya, dapat disimpulkan bahwa hasil penelitian ini membuktikan bahwa variabel motivasi kerja berpengaruh positif dan signifikan terhadap komitmen organisasi, yang dibuktikan dengan nilai koefisien regresi sebesar 0.334 , t hitung 1.720 dan sig. 0.097. Nilai ini menyatakan bahwa ada pengaruh positif yang signifikan terhadap komitmen organisasi.

Hasil penelitian ini membuktikan bahwa variabel etika kerja Islam berpengaruh, tapi tidak signifikan terhadap komitmen organisasi, yang dibuktikan melalui nilai koeffisien regresi sebesar 0.439, t hitung 2.260 dan sig. 0.032. Ketiga nilai ini menjelaskan adanya pengaruh yang positif dilihat dari t hitung dan nilai 
koefisien regresi yang positif, tapi tidak signifikan karena nilai signifikansi kurang dari 0.05 .

\section{Keterbatasan}

Penelitian ini bisa dikatakan jauh dari kata sempurna, karena masih terdapat keterbatasan-keterbatasan yang terdapat didalamnya. Keterbatasan- keterbatasan ini antara lain objek penelitian hanya bertumpu pada satu tempat saja, sehingga hasil yang diberikan hanya bermuara pada satu tempat itu saja, yaitu Kopkar Pura Group Kudus. Penelitian selanjutnya diharapkan dapat memperluas objek penelitiannya, agar hasil yang didapatkan bisa digeneralisasi.

Penelitian ini hanya menggunakan dua variabel bebas, sehingga hanya bisa mengetahui sumbangan pengaruh dari dua variabel tersebut, yang mana disini hanya memiliki nilai sebesar $34,9 \%$. Untuk penelitian yang akan datang diharapkan dapat menambah jumlah variabel bebas, agar sumbangan pengaruh yang diberikan akan lebih besar.

\section{Saran}

Berdasarkan hasil penelitian dan kesimpulan yang telah disajikan, maka selanjutnya peneliti menyampaikan saran-saran yang kiranya dapat memberikan manfaat kepada pihak-pihak yang terkait atas hasil penelitian ini. Adapun saran-saran yang dapat disampaikan adalah sebagai berikut, pertama, kecintaan pada organisasi merupakan hal yang harus selalu dipupuk sedini mungkin agar tercipta motivasi kerja yang dapat bermuara pada terciptanya komitmen organisasi. Kedua, motivasi kerja dan etika kerja Islam juga hendaknya dipelihara agar dalam menjalankan pekerjaannya, karyawan selalu melaksanakan dengan sebaik-baiknya atas kesadaran dirinya sendiri.

\section{DAFTAR PUSTAKA}

, 2002, Membudayakan Etos Kerja Islami, Gema Insani Press, Jakarta.

Abdul Aziz, Etika Bisnis Perspektif Islam, 2013, Alfabeta, Bandung.

Al-Qur'an surat Al Ankabuut ayat 69, Al-Qur'an dan Terjemahnya, Kementerian Urusan Agama Wakaf, Da’wah dan Irsyad Kerajaan Saudi Arabia, Mujamma' 
Malik Fahd Li Thiba'at Al Mushhaf Asysyarif, Medinah Munawwarah, 1997, Hlm. 638.

Ardana, Komang, dkk. 2008. Perilaku Keorganisasian. Edisi Pertama. Graha Ilmu. Yogyakarta.

Buchari Alma dan Donni Juni Priansa, 2009, Manajemen Bisnis Syariah, Alfabeta, Bandung, 2009.

Hadari Nawawi, 2011, Manajemen Sumber Daya Manusia Untuk Bisnis yang Kompetitif, Gadjah Mada University Press, Yogyakarta.

Khaerul Umam, Perilaku Organisasi, Pustaka Setia, Bandung, 2010, Hlm. 159.

Sopiah, 2008, Perilaku Organisasional, CV Andi Offset, Yogyakarta.

Sunarto, 2005, Manajemen Karyawan, Amus, Yogyakarta.

Toto Tasmara, 1995, Etos Kerja Pribadi Muslim, Dana Bhakti Wakaf, Yogyakarta. 